\title{
Penanaman Nilai Nasionalis Melalui Pembelajaran Budaya Lokal Sasak di Sekolah Dasar
}

\author{
Aswasulasikin $^{1}$, Sri Pujiani ${ }^{2}$, Yul Alfian Hadi ${ }^{3}$ \\ Universitas Hamzanwadi, MTs ${ }^{1,3}$. Mu'allimat NW Pancor ${ }^{3}$ \\ kien.ip12@gmail.com ${ }^{1}$, puji.kien@gmail.com²,yulhadi@gmail.com ${ }^{3}$
}

\begin{abstract}
Abstrak
Penelitian bertujuan untuk menanamkan nilai-nilai Nasionalis melalui Pembelajaran berbagai budaya lokal suku sasak yang ada di wilayah Lombok Nusa Tenggara Barat. Beberapa survey dari hasil penelitian menunjukan bahwa rasa nasionalisme generasi bangsa Indonesia sudah menurun diakibatkan oleh perkembangan teknologi dan digilasasi yang membabibuta menguasai generasi bangsa tanpa terkendali. Disisi lain ancaman masuknya budaya-budaya dari barat yang berpotensi yang dipertontonkan oleh wisatawan mancanegara dan pengaruh tontonan yang tidak bisa dikendalikan akan mengerus rasa nasionalisme generasi bangsa Indonesia. Sekolah Dasar sebagai Garda terdepan dalam mengantisipasi lunturnya jiwa nasionalisme generasi bangsa perlu berjuang keras dalam menanamkan rasa Nasionalisme generasi bangsa melalui pembelajaran yang akan memperkuat nilai-nilai nasionalisme, salah satu diantaranya adalah dengan terus memperkenalkan budaya lokal agar tidak kalah dengan masuknya budaya-budaya barat yang sangat berpotensi merusak rasa nasionalisme. Budaya lokal yang dimaksud dalam penelitian ini adalah penanaman budaya local suku sasak berupa kesenian dan makanan sasak. Penelitian ini dilakukan dengan pendekatan kualitatif deskriptif, dan mengambil subjek penelitian sekolah dasar di Kabupaten Lombok Timur, dengan mengambil beberapa sekolah sebagai role model penanaman nilainilai Nasionalisme melalui pembelajaran budaya sasak. Dari hasil penelitian dapat dijelaskan bahwa penanaman nilai nasionalis melalui pembelajaran budaya local sasak disekolah dasar masih belum maksimal dan tidak merata. Sebagian besar sekolah tidak memperkenalkan berbagai budaya yang dimiliki oleh suku sasak. Hal ini dibuktikan bahwa sebagian besar siswa sekolah dasar tidak mengenal budaya sasak yang beraneka ragam. Siswa sekolah dasar lebih memahami dan lebih cepat hafal tarian-tarian barat, india dari pada kesenian sasak; kemudian siswa lebih mengenal berbagai jenis-jenis makanan luar negeri, lebih mengenal kebuadayaan barat dari pada kebudayaan lokal sasak.
\end{abstract}

Kata kunci: Budaya Lokal, Nasionalisme, Sasak 


\section{PENDAHULUAN}

Para pendiri negara merumuskan dalam Pasal 1 ayat (1) UUD 1945 bahwa negara kesatuan yang berbentuk republik adalah negara yang tepat untuk menjadi rumah bersama bangsa Indonesia yang sangat majemuk guna melaksanakan nilai-nilai demi untuk mencapai cita-cita bangsa Indonesia yang merdeka sebagaimana tertuang dalam Pembukaan UUD 1945. Keyakinan tersebut dapat terbaca antara lain dalam Pidato Bung Karno 1 Juni 1945 yang menegaskan antara lain bahwa "Kita mendirikan suatu Negara kebangsaan Indonesia. Nationale adalah seluruh wilayah Indonesia yang merupakan wilayah kesatuan. Menurut geopolitik, maka Indonesialah adalah tanah air kita (Indriani, 2013; Kawentar, 2015; Rawantina \& Iriane, 2013). Indonesia yang bulat, bukan Jawa saja, bukan Sumatera saja, atau Borneo saja, atau Selebes saja, atau Ambon saja, atau Maluku saja, tetapi segenap kepulauan yang ditunjuk oleh Allah S.W.T. menjadi suatu kesatuan antara dua benua dan dua samudera, itulah tanah air kita.

Negara Kesatuan Republik Indonesia merupakan Negara yang terdiri dari ribuan pulau dan dihuni oleh berbagai RAS, kelompok etnis, bahasa dan budaya yang beraneka ragam. Berdasarkan UUD 1945 Pasal 1 ayat 1 NKRI (Negara Kesatuan Republik Indonesia) adalah negara kesatuan yang berbentuk Republik. Ketetapan ini sudah disusun dalam pasan 18 UUD 1945 ayat (1) yang menyatakan bahwa Negara Kesatuan Republik Indonesia terbagi atas daerah-daerah provinsi dan daerah provinsi itu terbadi atas kota dan kabupaten yang masing-masing kota, kabupaten dan provinsi tersebut memilki pemerintahan daerah yang diatur dengan Undang-Undang.

Nasionalisme merupakan paham atau ajaran untuk mencintai bangsa dan Negara sendiri atau kesadaran suatu anggota masyarakat yang secara potensial mempertahankan identitas, integritas, kemakmuran, dan kekuatan bangsa secara bersama-sama (Nurhakim, 2019). Berbicara nasionalisme berarti berbicara tentang rasa bangga menjadi suatu kesatuan dari keberagaman berbagai suku, kepercayaan, adat istiadat, dan perilaku sosial lainya yang menjadi satu kesatuan dalam bingkai "Bhineka Tunggal Ika" berada dalam satu bingkai Negara kesatuan yang disebut Indonesia. Menurut (Aswasulsikin, 2017; Gibson-Robinson \& Soedirdja, 1986) Nasionalisme adalah pandangan yang bertujuan untuk mengembangkan rasa nasional 
berdasarkan pemahaman dan rasa cinta terhadap budaya lokal yang diketahui dan difahami. Selanjutnya (Haryono, 2009; Ramdhani, Yuliastri, Sari, \& Hasriah, 2019; Zaenal, 2020) mengatakan bahwa nasionalisme merupakan kualitas dan integritas kesadaran nasional bangsa sehinga dimaknai dengan kesadaran nasional sebagai bangsa, subjek budaya dan Negara sekaligus sebagai subjek moralitas bangsa.

Perlu disadari bahwa nasionalisme adalah mesin besar yang menggerakkan dan mengawasi semua kegiatan kita, dan merupakan sumber inspirasi besar dari kemerdekaan bangsa Indonesia. Menurut (Siswoyo, 2013) nasionalis sejati adalah nasionalis yang nasionalismenya bukan nasionalisme tiruan dari nasionalisme bangsa lain, akan tetapi timbul dari rasa cinta akan manusia dan kemanusiaan. Selanjutnya (Alfaqi, 2015; Dewantara, 2016; Purwanto, 2001) mengatakan, Nasionalisme di Indonesia adalah paham kebangsaan yang mengajarkan persatuan dan kesatuan bangsa di atas kebhinekaan agama, budaya dan suku bangsa demi membentuk dan mempertahankan eksistensi kehidupan bernegara. Nasionalisme Indonesia juga bukanlah nasionalisme yang sempit sehingga dapat menimbulkan chauvinism, karena ideology Pancasila merupakan ideologi yang terbuka selama tidak membahayakan kelangsungan kehidupan berbangsa dan bernegara.

Nilai karakter nasionalis adalah cara berpikir, bersikap, dan berbuat yang menunjukkan kesetiaan, kepedulian, dan penghargaan yang tinggi terhadap bahasa, lingkungan fisik, sosial, budaya, ekonomi, dan politik bangsa, menempatkan kepentingan bangsa dan negara di atas kepentingan diri dan kelompoknya. Sedangkan subnilai nasionalis antara lain apresiasi budaya bangsa sendiri, menjaga kekayaan budaya bangsa, rela berkorban, unggul dan berprestasi, cinta tanah air, menjaga lingkungan, taat hukum, disiplin, menghormati keberagaman budaya, suku dan agama (Kementerian Pendidikan dan Kebudayaan, 2016).

Menurut (Affan, 2016; Fibrianto \& Bakhri, 2017; Setiawan, 2017); sikap nasionalisme adalah rasa Bangga yaitu bangga sebagai bangsa Indonesia, mencintai produk dalam negeri bangga pada budaya yang beraneka ragam, menghargai jasa para pahlawan dan mengutamanak kepentingan umum. anak bangsa. Artinya sikap nasionalis siswa sekolah dasar di kabupaten Lombok Timur ditunjukan dengan rasa bangga menjadi bangsa Indonesia dibuktikan dengan memahami dan mencintai 
budaya lokal suku sasak yang beraneka ragam; yang dilaksanakan dalam kehidupan sehari-hari yang tercermin dalam perilaku dan sikap siswa.

Menanamkan budaya lokal pada siswa sekolah dasar sebagai karakter dan budaya disekolah dan akan menjadi karakter dan menumbuhkan rasa nasionalisme siswa, dengan adanya pembelajaran budaya lokal di sekolah dasar (Kumbara \& Anom, 2008; Pawitro, 2011; Zaenal, 2020). Pembelajaran budaya lokal disekolah dasar akan dapat menjadikan siswa semakin cinta terhadap budaya bangsa dan Negara, disampaing itu sekolah dapat menunjukan kepada masyakat sekitar bahwa sekolah ikut serta melestarikan budaya local dengan memberikan pembelajaran berbagai budaya lokal untuk menanamkan rasa nasionalisme kepada siswanya.

Menurut (Kumbara \& Anom, 2008; Murahim, 2019; Siregar \& Nadiroh, 2016; Zaenal, 2020); Pembelajaran budaya lokal sasak dengan harapan dapat meningkatkan nilai-nilai nasionalisme siswa sekolah dasar akan menjadikan budayabuadaya asing yang akan merusak budaya bangsa Indonesia akan tersaring dan tidak cepat melunturkan budaya bangsa yang mengakibatkan nilai-nilai nasionalisme yang seharusnya tertanam pada generasi bangsa dan diimplementasikan dalam kehidupan sehari-hari. Menurut (Mas Kumaidi 2011, aswasulasikin) di era globalisasi dan digitalisasi ini nilai-nlai nasionalisme generasi bangsa sudah mulai luntur dan pada akhirnya akan hilang dari kehidupan generasi bangsa. Salah satu contoh hilangnya rasa nasionalisme anak bangsa yaitu hilangnya kecintaan mereka terhadap budaya budaya lokal. Menurut (Kumbara \& Anom, 2008; Murahim, 2019) Hilangnya kesenian gendang blek, jangger,cupak gerantang. Disisi lain budaya lokal sasak mulai terkikis misalnya makanan-makan tradisional sasak yang hampir punah, dan berbagai permainan tradisional yang sudah tidak dimainkan lagi oleh anak-anak dan generasi saat ini seperti permainan rempak, sungkit, sebok pete dan lain sebagainya.

Tantangan genarasi bangsa Indonesia ke depan dijelaskan pada paparan Moeldoko (2016) dalam acara Indonesia Lawyers Club disalah satu televise swasta, beliau mengingatkan generasi bangsa Indonesia tentang perkembangan kekinian telah melahirkan ancaman baru terhadap rasa nasionalisme di Indonesia, yaitu perebutan sumber energi dan sumber makanan (pangan dan air). Indonesia yang menjadi salah satu negara kaya dan terletak di garis khatulistiwa mempunyai sumber energi dan pangan yang melimpah. Indonesia ke depan akan menjadi rebutan dari 
berbagai kelompok atau negara sehingga akan timbul upaya-upaya untuk membubarkan NKRI sesuai dengan kepentingan mereka.

Berbagai budaya lokal sasak yang hampir punah tersebut disebabkan oleh perkembangan teknologi yang sangat menjamur. Anak - anak setingkat sekolah dasar sekarang lebih suka main gedged bermain game online, dengan berbagai jenis permainan di dalamnya. Anak-anak kecanduan bermain game dan lebih asyik sendiri dari pada berkomunikasi dan bermain dengan teman sebayanya. Kondisi inilah yang mengakibatkan generasi bangsa tidak mengenal berbagai jenis permainan tradisional, tidak mengetahui berbagai jenis makanan tradisional, dan tidak pernah mengetahui berbagai jenis kesenian lokal sasak sebagai hasanah budaya lokal sasak.

Untuk mengatasi permasalahan dan terkikisnya rasa nasionalisme generasi bangsa oleh akibat dari perkembangan teknologi yang sangat pesat dan masuknya budaya-budaya barat maka perlu adanya upaya maksimal yang harus dilakukan oleh berbagai elemen bangsa. Salah satunya dengan menanamkan nilai-nilai nasionalisme melalui pembelajaran budaya lokal sebagai salah satu langkah antisipasi masuknya budaya barat yang berakibat rusaknya budaya lokal dan berakita hilangnya kecintaan mereka terhadap budaya bangsa terutama budaya lokal yang berakibat hilangnya nilai-nilai nasionalisme generaasi bangsa Indonesia.

Berdasarkan deskripsi permasalahan di atas dapat digambarkan bahwa nilainilai nasionalisme generasi bangsa Indonesia sudah mulai terkikis, perlu adanya penanaman nilai nasionalisme tersebut melalui pembelajaran budaya lokal sejak dini yaitu dimulai dari siswa sekolah dasar, dalam hal ini pembelajaran budaya lokal sasak di sekolah dasar di Lombok Timur

\section{METODE PENELITIAN}

Penelitian ini merupakan penelitian dengan menggunakan pendekatan pendekatan kualitatif deskriptif yang diawali dengan melakukan analisis data sekunder mengenai gambaran terkait dengan kegiatan-kegiatan penanaman nilainilai nasionalisme pembelajaran budaya lokal suku sasak pada siswa sekolah dasar di Kabupaten Lombok Timur. Teknik pengumpulan data dilakukan dengan cara observasi, wawancara dan dokumentasi. Subjek penelitian sebagai sumber data dalam penelitian ini adalah bebepa sekolah yang melaksanakan pembelajaran muatan lokal sebagai sumber data primer. Setelah itu, data dan informasi yang 
diperoleh dianalisis data kualitatif dengan skema analisis kualitatif oleh (Setyosari, 2016; Sugiyono, 2011). Untuk mengecek keabsahan data hasil penelitian dilakukan triangulasi, yaitu pengecekan data dari berbagai sumber untuk mendapatkan data dari sumber yang berbeda dengan teknik yang sama.

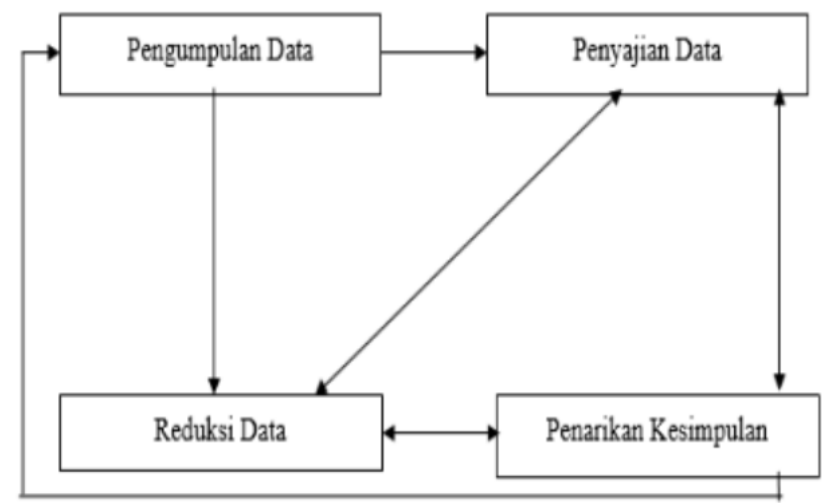

Gambar 1: Skema analisis data Kualitatif (sugiyono, 2008)

\section{HASIL DAN PEMBAHASAN}

\section{Nilai-Nilai Nasionalisme}

Nasionalisme merupakan adanya rasa bangga, memiliki, menghargai, menghormati, dan loyalitas pada negara dan bangsa yang dimiliki oleh setiap individu dan tercermin pada perilaku dalam kehidupan sehati-hari. Rasa Nasionalisme tersebut akan membentuk prilaku invidu generasi bangsa untuk membela negaranya, melindungi bangsanya, dengan terus melestarikan budaya bangsanya. Secara garis besar (Aswasulasikin Aswasulasikin, Dwiningrum, \& Sumarno, 2015; Indriani, 2013; Marwati, Prihartanti, \& Hertinjung, 2016), Endah Marwati (2016) merinci makna nasionalis sebagai berikut: (1) Paham yang menempatkan kesetiaan individu kepada Negara dan bangsa. (2) Tingginya semangat kebangsaan, yaitu semangat cinta terhadap bangsa dan tanah air, (3) Sikap politik dan sosial dari kelompok-kelompok suatu bangsa yang mempunyai kesamaan kebudayaan. Bangsa dan wilayah serta kesamaan cita-cita dan tujuan sehingga merasakan adanya kesetiaan mendalam terhadap kelompok bangsa itu.

Menurut, (Faiziyah, 2017; Gunawan, 2012; Moesa, 2007; Supardan, 2013) bangsa Indonesia saat ini mengalami krisis nasionalisme, hal ini disebabkan oleh perkembangan teklogi dan digitalisasi yang sangat pesat. Perkembangan Teknologi dengan penyebaran dan tingkat keterimaanya sangat ditinggi pada semua level 
masyarakat sangat mempengaruhi nilai-nilai nasionalisme yang semakin luntur. Faktanya; Perkembangan media sosial dapat menggerus budaya bangsa misalnya anak-anak zaman sekarang lebih senang bermain sosial media dari pada berdiskusi atau bersilaturrahmi dengan teman/kawan yang ada didekatnya, mereka lebih asyik bermain dengan media sosial, main game, main aplikasi lainya daripada bermain dengan teman sebayanya. Hal tersebut mengakibatkan budaya lokal semakin tergerus dan bahkan ada yang punah.

Penanaman nilai-nilai Nasionalisme di sekolah dapat dilakukan dengan berbagai macam kegiatan misalnya: pertama upacara bendera yang dilaksanakan pada setiap hari senin karena nilai nilai yang terkandung dalam pelaksanaan kegiatan tersebut adalah membiasakan siswa untuk menghargai jasa para pahlawan, meningkatkan kemampuan kepemimpinan siswa, menanamkan kemandirian, jiwa patriotism, serta membangkitkan peran siswa dalam berbangsa dan bernegara. Kedua memasukan budaya lokal dalam kegiatan sekolah, misalnya memperkenalkan berbagai jenis suku bangsa dengan berbagai macam budayanya, memperkenalkan kesenian (music, tari, dan lagu) berbagai macam daerah agar tidak tergerus oleh budaya barat yang dibantu oleh perkembangan teknologi. Memperkenalkan berbagai jenis makanan lokal khas masing-masing daerah atau masing-masing suku yang ada di Indonesia.

Nilai-nilai Nasionalisme sangat penting dimiliki oleh siswa untuk menjaga marwah nilai-nilai budaya bangsa dan negara yang tertanam dalam karakter anakanak bangsa sejak dini. Menanamkan rasa cinta terhadap budaya bangsa melalui pembelajaran merupakan disekolah dasar merupakan langkah awal menguatkan nilai-nilai nasionalis melalui pelestarian berbagai budaya lokal di Nusantara.

Melihat kondisi tersebut perlu adanya upaya untuk menumbuhkan nilai-nilai nasionalisme mulai dari tingkat sekolah dasar dengan memperkenalkan budayabudaya lokal melalui proses pembelajaran. Menumbuhkan nilai-nilai nasionalisme dapat dilakukan melalui pembelajaran budaya lokal disekolah dasar. Upaya tersebut dilakukan dengan proses pembelajaran dengan pembiasaan kepada siswan sehingga akan terbentuk karakter nasionalisme pada anak bangsa sejak dini (Irhandayaningsih, 2012; Musafiyono \& Setyowati, 2014; Muthoharoh, 2012; Putri, 2018). Dilihat dari sudut pandang filsafat, budaya lokal bukan hanya berfungsi 
menjadi filter ketika terjadi pengikisan budaya bangsa oleh perkembangan teknologi. Nilai budaya lokal sebagai pedoman moral dalam menyelesaikan krisis nilai-nilai nasionalisme.

Penelitian ini menggali bagaimana penanaman nilai-nilai nasionalis melalui pembelajaran budaya lokal sasak pada siswa sekolah dasar dikabupaten Lombok Timur. Peranan penting kearifan lokal sasak dipahami sebagai bentuk warisan kekayaan yang harus dilestarikan. Nilai-nilai yang terkandung dalam pembelajaran budaya sasak dapat dijadikan pedoman dalam berprilaku dimasyarakat. Karena fungsi budaya lokal dapat sebagai pedoman dalam bersikap dan berprilaku dimasyarakat, menjaga hubungan antara manusia dengan lingkungan sekitar, menjaga hubungan manusia dengan tuhan, sehingga budaya lokal sasak merupakan identitas suku bangsa sasak yang berdomisili di pulau Lombok. Nilai-nilai yang terkandung dalam budaya lokal sasak antara lain: nilai-nilai religious, sosial, estetika, politik, dan kepemimpinan.

\section{Budaya Lokal Sasak}

Penanaman nilai-nilai nasionalis melalui Pembelajaran budaya lokal sasak dapat dilakukan dengan mengadaptasi dan menambahkanya dalam kurikulum pembelajaran di sekolah dasar, dengan harapan dapat membentuk karakter anak bangsa yang cinta terhadap budaya lokal dan cinta terhadap budaya bangsa dan pada akhirnya akan menumbuhkan nilai-nilai nasionalisme (Kumbara \& Anom, 2008; Ramdhani et al., 2019; Zubair, Ismail, \& Alqadri, 2019).

Menurut (A Aswasulasikin, Ibrahim, \& Hadi, 2020; Faiziyah, 2017; Pawitro, 2011; Setiawan, 2017; Zaenal, 2020) Nilai-nilai budaya tradisional dapat diketahui melalui konsep kehidupan dalam bertindak dan berprilaku yang umumnya merepresentasikan lakatnya aspek nilai budi pekerti luhur bangsa sehingga akan menjadi pandangan Falsafah hidup bangsa Indonesia. Konsep kehidupan tersebut cendrung menjaga keseimbangan berbangsa dan bernegara, sebagai cerminan hubungan haronis antara manusia, lingkungan, dan sang khaliq. Hubungan tersebut merupakan wujud dari budaya lokal masyarakat tradisional dari berbagai suku bangsa dalam menjaga keseimbangan dan keharmonisan kehidupan berbangsa dan bernegara. 
Budaya lokal sasak saak ini cendrung terpinggirkan atau bahkan beberapa sudah punah dan tidak lagi dikenal oleh generasi-generasi berikutnya. Budaya lokal sasak sebagian besar terisolasi oleh generasi muda karena dianggap sudah tidak sesuai lagi dengan kondisi saat ini. Budaya lokal sasak hamper semuanya tergerus dan punah disebabkan karena internalisasi budaya luar melalu berbagai media. Perkembangan ternologi memiliki andil yang sangat besar dalam merusak budaya lokal sampai keakar-akarnya,

Melihat kondisi seperti ini sekolah sebagai benteng terakhir perlu mempersiapkan siswa sebagai garda terdepan dalam melestarikan budatya lokal sasak yang hampir punah dan jumlahnya sangat banyak. Dari hasil wawancara dan observasi dibeberapa sekolah dikabupaten Lombok Timur, siswa tidak mengenal budaya lokal sasak. Mereka tidak tahu beberapa alat musik dan kesenian sasak misalnya ketika ditanya apakah mereka tahu tentang "gendang belek" sebagian besar mereka tidak tahu, mereka tidak tahu gendang belek adalah alat music tradisional sasak. dan pertanyaan dilanjutkan, apakah mereka mengenal tarian sasak?. sebagian mereka tidak mengenal dan tidak tahu tarian tradisional sasak. ketika diminta memperaktikan tarian jangger (gandrung) mereka tidak tahu. Tetapi ketika diminta memperagakan tarian ala india, tarian barat, dan tarian korea sebagai dari mereka dengan lincahnya memperagakan tarian-tarian tersebut. Mirisnya lagi anak-anak sekolah dasar sebagian sangat hafal dan lihai menari atau berdancing alaala barat dan india.

Budaya lokal sasak hamper punah karena siswa tingkat SD dikabupaten Lombok Timur tidak mengenal dan memahami budaya lokal sasak. dari hasil observasi dan wawancara dengan beberapa guru dan kepala sekolah dasar di Kabupaten Lombok Timur dapat dideskripsikan bahwa, pengenalan budaya lokal sasak tidak dapat dilaksanakan dalam proses pembelajaran. Sekolah hanya menempatkan budaya lokal sasak pada ektra kurikuler yang dilatih pada siswa sebagai peminatan seperti menari, memperkenalkan beberapa jenis najanan sasak. terkait dengan kesenian sasak, sebagian besar sekolah tidak pernah memperkenalkan kesenian sasak sehingga sangat wajar siswa sekolah dasar tidak tahu dan tidak kenal dengan kesenian sasak. dari hasil observasi dibeberapa sekolah, pagi hari sebelum masuk ke kelas siswa diminta untuk dancing ala-ala korea, india dan barat, bukan 
menanamkan dan mengajarkan tarian sasak. begitu juga lagu-lagu, sebagian besar sekolah di Lombok Timur mengajarkan anak-anak bernyanyi lagu-lagu terkini dan yang viral dari pada mengajar mereka lagu-lagu sasak yang lebih banyak bernuansa religious dan motivasi.

Kemudian terkait makanan sasak, siswa SD tidak mengenal jenis-jenis jajanan sasak. padahal orang sasak memiliki budaya yang perlu dilestarikan dalam hal makanan (jajanan). Sebagai contoh pada pelaksaanaan Perayaan Hari Besar Islam (PHBI) seperti maulid Nabi Besar Muhammad SWA., Isro' Mi'raj, Nuzulul Qur'an, Hari Raya Idul Fitri, dan Hari raya Idul adha; Masyarakat berbondong-bondong membuat jajanan sasak dan dibawa ke masjid atau kemusolla menjadi sajian khas saat pelaksaan kegiatan hari besar islam tersebut. Tetapi saat ini siswa SD tidak lagi mengenal jenis-jenis jajanan sasak tersebut.

Kemudian terkait budaya sasak yang dulunya sangat kental dan menjadi bagian kehidupan masyarakat sasak adalah gotong royong, pola gotong royong merapakan salah satu kegiatan budaya sasak dan yang menjadi budaya nasional. Tetapi dengan pesat perkembangan teknologi membuat komunikasi antara manusia yang satu dengan yang lainya tidak lagi harus bertatap muka. Gotong royong dan silaturrahmi yang menjadi bagian dari budaya sasak tidak lagi sering terlihat.

Melihat kondisi dari temuan penelitian tersebut di atas maka terlihat jelas bahwa budaya lokal sasak sudah mulai tergerus dan hampir punah, siswa-siswa Sekolah Dasar yang menjadi genersi penerus masyarakat dalam menjalankan budaya lokal sasak sudah tidak tahu dan tidak lagi mengenal budaya-budaya lokal sasak. tidak pernah lagi terdengar lantunan lagu-lagu sasak yang bernuansa regilius dan motivasi bagi anak bangsa. Bahkan ditemukan beberapa Sekolah menganggap pelajaran muatan lokal tidak harus budaya lokal. Sebagaian besar kepala sekolah menganggap tidak penting lagi memperkenalkan berbagai jenis budaya lokal.

Hambatan sekolah dalam menanamkan budaya lokal sasak di Sekolah Dasar adalah tidak adanya pedoman atau petunjuk teknis pembelajaran muatan lokal sasak. budaya sasak tidak bisa dimasukan dalam kurikulum karena tidak dijadwalkan oleh dinas pendidikan sebagai pemegang kebijakan, sehingga pihak sekolah tidak berani memasukan pembelajaran budaya lokal sasak sebagai pelajaran formal. Oleh karena itu sebagai sekolah memasukan kesenian sasak sebagai bagian ekstra kurikuler. 
Dari hasil penelitian diketemukan beberapa permasalahan dalam penumbuhan nilai karakter nasionalis, baik dari sisi sarana dan prasarana, pemahaman guru maupun dari sisi proses pembelajaran serta sumber daya belajarnya. Tidak hanya itu, guru juga merasa kesulitan dalam mendapatkan referensi yang berhubungan dengan materi atau sumber belajar mengenai budaya lokal sasak. Buku-buku yang terkait dengan berbagai budaya lokal sasak yang akan menjadi acuan pembelajaran masih sangat kurang bahkan tidak ada.

Hal ini semakin dipersulit dengan belum memadainya kreativitas guru dalam menumbuhkan nilai-nilai nasionalis dalam proses belajar mengajar.

\section{SIMPULAN}

Budaya lokal sasak merupakan salah satu budaya penunjang karakter nasional. Pada dasarnya budaya lokal sasak memiliki nilai-nilai yang terkandung dalam nilai nasionalis. Pelesetarian budaya lokal sasak merupakan keikut sertaan suku sasak dalam melestarikan budaya bangsa. Seiring perkembangan zaman dan pesatnya perkembangan teknologi mengakibatkan semua budaya tradisional sasak hampir punah.

Siswa sekolah dasar sebagai generasi penerus utama budaya tradisional sasak tersebut sudah tidak mengenal lagi budaya-budaya lokal sasak, mereka lebih mengenal dan lebih akrab dengan budaya-budaya barat yang sering mereka lihat dan pelajari melalui media sosial. Lagu, tarian, dancing yang sering mereka lihat di berbagai media sosial juga sering dipraktikan oleh siswa sekolah dasar sebelum mereka masuk ke kelas. Pihak sekolah tidak menekankan pengenalan budaya lokal sasak (seperti tarian, alat music, makanan, dan perilaku) budaya sasak yang tercermin dalam budaya gotong royong.

Kondisi ini disebabkan oleh guru-guru tidak memiliki refrensi dan pedoman dalam mengajarkan budaya lokal sasak di sekolah dasar. Guru-guru sekolah dasar tidak mengajarkan budaya lokal sasak karena tidak ada kebijakan dinas pendidikan kabupaten yang menekankan pentingnya menanamkan budaya lokal sasak untuk melestarikan kerifan lokal melalui pembelajaran budaya lokal sasak. budaya lokal sasak sebaiknya dimasukan dalam kurikulum sehingga para guru memiliki pedoman dalam pembelajaran. 


\section{DAFTAR PUSTAKA}

Affan, M. H. (2016). Membangun kembali sikap nasionalisme bangsa Indonesia dalam menangkal budaya asing di era globalisasi. Jurnal Pesona Dasar, 3(4).

Alfaqi, M. Z. (2015). Memahami Indonesia Melalui Prespektif Nasionalisme, Politik Identitas, Serta Solidaritas. Jurnal Pendidikan Pancasila Dan Kewarganegaraan, 28(2).

Aswasulasikin, A, Ibrahim, D. S. M., \& Hadi, Y. A. (2020). Menciptakan Lingkungan Ramah Literasi Melalui Pelibatan Masyarakat dan Orang Tua. Jurnal Dimaswadi, 1(1), 1-7.

Aswasulasikin, Aswasulasikin, Dwiningrum, S. I. A., \& Sumarno, S. (2015). Tuan Guru Sebagai Tokoh Pembangunan Pendidikan di Pedesaan. Jurnal Pembangunan Pendidikan: Fondasi Dan Aplikasi, 3(1), 1-10.

Aswasulsikin, A. (2017). Partisipasi Masyarakat Desa Dalam Pembangunan Pendidikan. Deepublish.

Dewantara, A. W. (2016). Gotong-Royong Menurut Soekarno Dalam Perspektif Aksiologi Max Scheler, Dan Sumbangannya Bagi Nasionalisme Indonesia. Universitas Gadjah Mada.

Faiziyah, A. (2017). Transforamsi Nilai-Nilai Religius dalam Pembentukan Karakter; Studi Kasus Pada Siswa Smk Arrahmah Purwotengah Papar Kediri. Jurnal Intelektual: Jurnal Pendidikan Dan Studi Keislaman, 7(1), 12-21.

Fibrianto, A. S., \& Bakhri, S. (2017). Pelaksanaan Aktivitas Ekstrakurikuler Paskibra (Pasukan Pengibar Bendera) Dalam Pembentukkan Karakter, Moral Dan Sikap Nasionalisme Siswa Sma Negeri 3 Surakarta. Jurnal Moral Kemasyarakatan, 2(2), 75-93.

Gibson-Robinson, C., \& Soedirdja, H. (1986). Transgressive development of Miocene reefs, Salawati Basin, Irian Jaya.

Gunawan, R. (2012). Nasionalisme Pemuda Dalam Perubahan Sosial.

Haryono, A. (2009). Authentic assessment dan pembelajaran inovatif dalam pengembangan kemampuan siswa. Jurnal Pendidikan Ekonomi, 2(1), 1-10.

Indriani, S. (2013). Penanaman Nilai-Nilai Nasionalisme Melalui Pembelajaran Pendidikan Kewarganegaraan (Studi Kasus di MTs Negeri Surakarta II Tahun 2013). Universitas Muhammadiyah Surakarta.

Irhandayaningsih, A. (2012). Peranan Pancasila dalam menumbuhkan kesadaran nasionalisme generasi muda di era global. Humanika, 16(9).

Kawentar, F. (2015). Pelaksanaan Penanaman Nilai Nasionalisme di SDN II Klaten. 
Basic Education, 4(9).

Kumbara, A., \& Anom, N. (2008). Konstruksi Identitas Orang Sasak di Lombok Timur, Nusa Tenggara Barat. Humaniora, 20(3), 315-326.

Marwati, E., Prihartanti, N., \& Hertinjung, W. S. (2016). Pelatihan Berpikir Optimis untuk Meningkatkan Harga Diri pada Remaja di Panti Asuhan. Indigenous: Jurnal Ilmiah Psikologi, 1(1), 23-31.

Moesa, A. M. (2007). Nasionalisme Kiai; Konstruksi Sosial Berbasis Agama. LKIS PELANGI AKSARA.

Murahim, N. F. N. (2019). Nilai-Nilai Budaya Sasak Kemidi Rudat Lombok: Perspektif Hermeneutika. Mabasan, 5(2).

Musafiyono, W., \& Setyowati, R. N. (2014). Peran Orang Tua Dalam Menumbuhkan Nasionalisme Pada Anak Usia Sekolah Dasar (Di Perumahan Griya Kencana, Desa Mojosarirejo, Kecamatan Driyorejo, Kabupaten Gresik). Kajian Moral Dan Kewarganegaraan, 3(2), 1076-1094.

Muthoharoh, A. I. (2012). Pendidikan nasionalisme melalui pembiasaan di SD Negeri Kuningan 02 Semarang Utara. Universitas Negeri Semarang.

Nurhakim, A. (2019). Peran Guru PAI Dalam Menanamkan Pengamalan Nilai-Nilai Pancasila dan Nasionalisme pada Siswa di SMAN 6 dan 18 Kabupaten Tangerang. UIN SMH BANTEN.

Pawitro, U. (2011). Prinsip-Prinsip "Kearifan Lokal" Dan Kemandirian "Berhuni" Pada Arsitektur Rumah Tinggal "Suku Sasak" Di Lombok Barat. Simposium Nasional RAPI X FT UMS. Surakarta: Universitas Muhammadiyah Surakarta, $1-9$.

Purwanto, B. (2001). Memahami Kembali Nasionalisme Indonesia. Jurnal Ilmu Sosial Dan Politik, 4(2001).

Putri, A. S. H. (2018). Penanaman nilai nasionalisme melalui kegiatan upacara hari senin pada siswa SMP negeri 3 Sawit kabupaten Boyolali Tahun Pelajaran 2017/2018. Surakarta: Universitas Muhamadiyah Surakarta.

Ramdhani, S., Yuliastri, N. A., Sari, S. D., \& Hasriah, S. (2019). Penanaman NilaiNilai Karakter melalui Kegiatan Storytelling dengan Menggunakan Cerita Rakyat Sasak pada Anak Usia Dini. Jurnal Obsesi: Jurnal Pendidikan Anak Usia Dini, 3(1), 153-160.

Rawantina, I., \& Iriane, N. (2013). Penanaman nilai nasionalisme dan patriotisme untuk mewujudkan pendidikan karakter pada mata pelajaran pendidikan kewarganegaraan siswa kelas x sma negeri 4 sidoarjo. Kajian Moral Dan Kewarganegaraan, 1(1), 39-54. 
Setiawan, D. (2017). Kontribusi Tingkat Pemahaman Konsepsi Wawasan Nusantaraterhadap Sikap Nasionalisme dan Karakter Kebangsaan. JUPIIS: Jurnal Pendidikan Ilmu-Ilmu Sosial, 9(1), 20-33.

Setyosari, H. P. (2016). Metode penelitian pendidikan \& pengembangan. Prenada Media.

Siregar, S. M., \& Nadiroh, N. (2016). Peran Keluarga Dalam Menerapkan Nilai Budaya Suku Sasak Dalam Memelihara Lingkungan. Jurnal Green Growth Dan Manajemen Lingkungan, 5(2), 28-40.

Siswoyo, D. (2013). Philosophy of education in Indonesia: Theory and thoughts of institutionalized state (Pancasila). Asian Social Science, 9(12), 136.

Sugiyono, P. (2011). Metodologi penelitian kuantitatif kualitatif dan R\&D. Alpabeta, Bandung.

Supardan, D. (2013). Tantangan Nasionalisme Indonesia Dalam Era Globalisasi. Lentera (Jurnal Ilmu-Ilmu Sejarah, Budaya Dan Sosial), 2(04), 37-72.

Zaenal, M. (2020). Rekonstruksi Nilai-Nilai Kearifan Lokal Suku Sasak Sebagai Suplemen Materi Ajar Pendidikan IPS Pada SMP Negeri 3 Pujut Kabupaten Lombok Tengah. Reform: Jurnal Pendidikan, Sosial Dan Budaya, 1(02), 35-48.

Zubair, M., Ismail, M., \& Alqadri, B. (2019). Rekonstruksi Nilai Pancasila Dengan Pendekatan Local Wisdom Masyarakat Sasak Sebagai Upaya Penyelamatan Identitas Nasional Melalui Mata Kuliah Kewarganegaraan Di Universitas Mataram (Studi deskriftif di Nusa Tenggara Barat). Jurnal Ilmiah Pena: Sains Dan Ilmu Pendidikan, 1(2), 1-8. 